\title{
THE POTENTIAL IMPACT OF ASH MERAPI VOLCANO ERUPTION 2010 IN YOGYAKARTA, INDONESIA, FOR THE ENVIRONMENT AND HUMAN HEALTH
}

\author{
Wawan Budianta* \\ Department of Geological Engineering, Universitas Gadjah Mada
}

\begin{abstract}
The eruptions of Merapi Volcano began in late October 2010 and continued into early November 2010. Among parts of materials ejected by Merapi Volcano, volcanic ash is considered to be a respiratory health hazard because of several potentially toxic components: respirable crystalline silica and metals. The objective of this study is to review the grain size of volcanic ash and to analyze the composition of volcanic ash which is suspected to carry a variety of potentially toxic elements. The result of this study shows that very fine grain size of volcanic ash were detected which has a potential to become respiratory problem trigger. The heavy metals were also detected in ash samples. On the other hand, total sulfur content was also considered high and the source of this sulfur was sulfur dioxide during eruption.
\end{abstract}

Keywords: Merapi volcano, eruption, volcanic ash, health hazard, toxic elements.

\section{Introduction}

The 2010 eruptions of Merapi Volcano began in late October 2010 when this volcano in Central Java, Indonesia began an increasingly violent series of eruptions that continued into November 2010. Among parts of materials ejected by Merapi Volcano, volcanic ash may cause accute

*Corresponding author: W. BUDIANTA, Department of Geological Engineering, Universitas Gadjah Mada. Jl. Grafika 2 Kampus UGM, Yogyakarta, Indonesia. E-mail: wbudianta@ugm.ac.id respiratory diseases (e.g. asthma and bronchitis) and has the potential to instigate chronic diseases such as silicosis and lung cancer. Volcanic ash is considered a respiratory health hazard because of several potentially toxic components, such as respirable crystalline silica. Volcanic ash can carry a variety of potentially toxicadsorbed elements such as $\mathrm{Cl}, \mathrm{S}, \mathrm{Na}, \mathrm{Ca}, \mathrm{K}, \mathrm{Mg}$ and $\mathrm{F}$ as well as metals such as $\mathrm{Pb}, \mathrm{Hg}, \mathrm{Cu}$, $\mathrm{Zn}, \mathrm{Cd}$ and As and other potentially pathogenic trace elements. These elements may be carried hundreds of kilometres in a volcanic plume and will be inhaled with the ash particles unless leaching occurs first.

Both acute and chronic respiratory diseases can only occur if particles are sufficiently small to enter the respiratory system. Therefore, the first step in assessing the potential toxicity of volcanic ash should be to rapidly determine whether the particles are sufficiently small to enter the lungs. In this context, the size of a particle is conventionally described by its diameter. However, diameter definitions vary according to the style of particle measurement.

In general, particles $>15 \mathrm{~mm}$ diamater will not penetrate the respiratory tract beyond the nose. Those between $10-15 \mathrm{~mm}$ diameter will settle in the upper respiratory tract and may cause irritation of the throat and nasal passage. Particles less than $10 \mathrm{~mm}$ diameter, the 'thoracic' fraction, may enter the bronchioles and it is thought that it is this fraction that causes lung irritation, inflammation, asthma and bron- 
chitis. Fine particles less than $4 \mathrm{~mm}$ diameter are termed 'respirable'. Respirable particles can penetrate the alveolar region of the lung where chronic, particle-related respiratory diseases, such as silicosis, are activated. Ultrafine particles (sub-2.5 mm diameter, and particularly those in the nanoparticle range, sub$0.5 \mathrm{~mm}$ ) may have even greater disease-causing potential (Horwell, 2007)

On the other hand, the ash composition was also suspected consists of fresh volcanic material which can carry a variety of metals such as $\mathrm{Pb}, \mathrm{Hg}, \mathrm{Cu}, \mathrm{Zn}, \mathrm{Cd}$ and $\mathrm{As}$ and other potentially-pathogenic trace elements (Fiantis et al., 2009). Beside respiratory health effect to human health, volcanic ash may result in short-term physical and chemical changes in water quality because of the existence of readily soluble material on freshly erupted volcanic ash which has been documented by many researchers (Smith et al., 1982).

This research two goals, all of which are essential to forwarding our understanding of health hazard assessment through observe the volcanis material impact: (1) to review the grain size of volcanic ash, (2) to analyze the composition of volcanic ash which suspected carry a variety of potentially-toxic elements.

\section{Material and methods}

Fifteen volcanic ash samples were collected from Merapi volcano at varying distances from the volcano, ranging from a few hundred meters to several kilometers, in Sleman District (5 $\mathrm{km})$, Yogyakarta City $(25 \mathrm{~km})$, Muntilan City $(15 \mathrm{~km})$, Klaten District $(20 \mathrm{~km})$ and Bantul District $(40 \mathrm{~km})$. All samples were collected one day after eruption in November 5, 2010.

As mentioned earlier, the important step in assessing the potential health effect of volcanic ash should be to rapidly determine whether the particles are sufficiently small to enter the lungs, and the particle size analysis will be investigated in the beginning, by using sieving and hydrometer test. X-ray diffraction was conducted to investigate the presence of crystalline ash, such as silica and other potentiallypathogenic trace elements which has potential to produce respiratory health. Trace element analysis was carried out to investigate the composition of the the ash sample, which can be consisted of several heavy metals.

\section{Result and Discussion}

Volcanic ash was formed during explosive volcanic eruptions. Explosive eruptions occur when gases dissolved in molten rock (magma) expand and escape violently into the air and also when water is heated by magma and abruptly flashes into steam. The force of the escaping gas violently shatters solid rocks. Expanding gas also shreds magma and blasts it into the air, where it solidifies into fragments of volcanic rock and glass. Once in the air, wind can blow the tiny ash particles tens to thousands of kilometers away from the volcano. Volcanic ash fall deposits are composed of various proportions of glass shards, crystals/minerals and lithic particles (fragments of older material).

\subsection{Grain size of volcanic ash}

Table 1 shows the amount of material in the health-pertinent fractions for volcanic ash samples from all sampling location, measured by sieving and hydrometer test. There were some literatures on grain size result of volcanic ash (Bonnadona, et al., 2005a, Bonnadona, et al., 2005b), but it was only in health-related papers that data are presented on the healthrelevant fractions (Horwell, et al., 2003, Baxter, et al., 1999, Hornwell, 2007). Furthermore, the health relevant 'respirable' fraction was reclassified from sub-10 mm to sub-4 mm in the 1990s (Quality of Urban Air Review Group, UK, 1996) to date and Horwell et al. (2003) present the only published data for the sub- $4 \mathrm{~mm}$ and sub$10 \mathrm{~mm}$ fractions. Table 1 shows that the amount of respirable material $(<4 \mathrm{~mm})$ in bulk ash samples varies from $3-5 \mathrm{vol} \%$.

Theoritically, the amount of fine-grained material in each sample reflects several factors including: (i) the style and dynamics of the eruption. Volcanic ash is produced by fragmentation of magma. (ii) processes within the eruption plume (including composition of volcanic ash 
Table 1: Grain size distribution respirable volcanic ash

\begin{tabular}{l|c|c|c|c}
\hline \multirow{2}{*}{} & \multicolumn{4}{|c}{ Grain-size distribution, cumulative vol \% } \\
\cline { 2 - 5 } & $<4 \mu \mathrm{m}$ & $<10 \mu \mathrm{m}$ & $<15 \mu \mathrm{m}$ & $<63 \mu \mathrm{m}$ \\
\hline Sleman $(9 \mathrm{~km})$ & 4.49 & 6.29 & 17.97 & 64.66 \\
\hline Sleman $(10 \mathrm{~km})$ & 4.44 & 7.11 & 18.66 & 66.93 \\
\hline Sleman $(8 \mathrm{~km})$ & 4.36 & 6.11 & 18.32 & 66.15 \\
\hline Sleman $(7 \mathrm{~km})$ & 3.58 & 5.36 & 18.78 & 65.79 \\
\hline Bantul $(20 \mathrm{~km})$ & 5.34 & 7.12 & 16.91 & 63.48 \\
\hline Klaten $(17 \mathrm{~km})$ & 4.90 & 7.35 & 15.67 & 64.05 \\
\hline Yogyakartaa City $(12 \mathrm{~km})$ & 4.73 & 6.88 & 18.06 & 67.99 \\
\hline Yogyakartaa City $(15 \mathrm{~km})$ & 4.30 & 6.45 & 20.63 & 65.65 \\
\hline Magelang $(10 \mathrm{~km})$ & 4.71 & 6.85 & 14.56 & 61.97 \\
\hline Muntilan $(10 \mathrm{~km})$ & 4.51 & 7.21 & 20.74 & 67.40 \\
\hline Muntilan $(11 \mathrm{~km})$ & 3.58 & 4.92 & 11.19 & 55.75 \\
\hline Sleman $(4 \mathrm{~km})$ & 4.09 & 5.46 & 12.73 & 56.54 \\
\hline Sleman $(5 \mathrm{~km})$ & 3.59 & 4.49 & 10.78 & 53.42 \\
\hline Magelang $(11 \mathrm{~km})$ & 3.06 & 3.94 & 7.00 & 55.84 \\
\hline Sleman $(3 \mathrm{~km})$ & 3.57 & 5.35 & 9.81 & 54.68 \\
\hline
\end{tabular}

magma fragmentation, column dynamics, wind dispersal and interaction with ice, water and electrostatic forces) and (iii) the distance from the volcano to the site of sample deposition.

Table 1 was presented with varying distance of sample location and it was clear show that there was no correlation between the distance of sampling location and the amount of fine ash produced. The size of ash particles that fall to the ground generally decreases exponentially with increasing distance from a volcano. Also, the range in grain size of volcanic ash typically diminishes downwind from a volcano (becoming progressively smaller). The 2010 Merapi eruptions was highly explosive, expressed on the relatively high on the VEI scale (scale of 4), whereas recently eruption was usually less than 3 in VEI scale (Voight, et al., 2000). This highlights a fundamental concept in ash generation from explosive fragmentation of fresh magma and also shows the effect of preferential elutriation of fine material into a lofting co-ignimbrite plume.

Following quantification of the healthrelevant size fractions, it is instructive to compare the results of other volcanic eruptions, especially of those where health hazard assessment has been carried out. For example, the population near Sakurajima volcano, Japan, has also been subjected to at least twelve epi- demiological or clinical studies (Horwell and Baxter, 2006). However, results here show that $<1 \%$ of the ash from Sakurajima volcano is respirable. This result is based on just one sample, however, and may not be representative of normal volcanic material deposition.

\subsection{Composition of volcanic ash}

Figure 1 show the resut of XRD analysis in ash sample in Yogyakarta City, and Table 2 gives the several data collected from X-ray diffraction. The figure and table shows that crystalline silica was present and plagioclase was major component in samples. The presence of crystalline silica was indicated that there were potential to become a respiratory problem. The crystalline silica was described as "free" silica because the silicon dioxide compound is not attached to another element to create a new mineral; for example, magnesium to form the mineral olivine. Exposure to respirable particles of free crystalline silica can lead to silicosis, a disease resulting in scar in the lungs and impairment of their function. Although there have been no documented cases of silicosis attributed to free crystalline silica in volcanic ash from eruptions in the past few decades, detailed studies for lengthy periods of time necessary to 


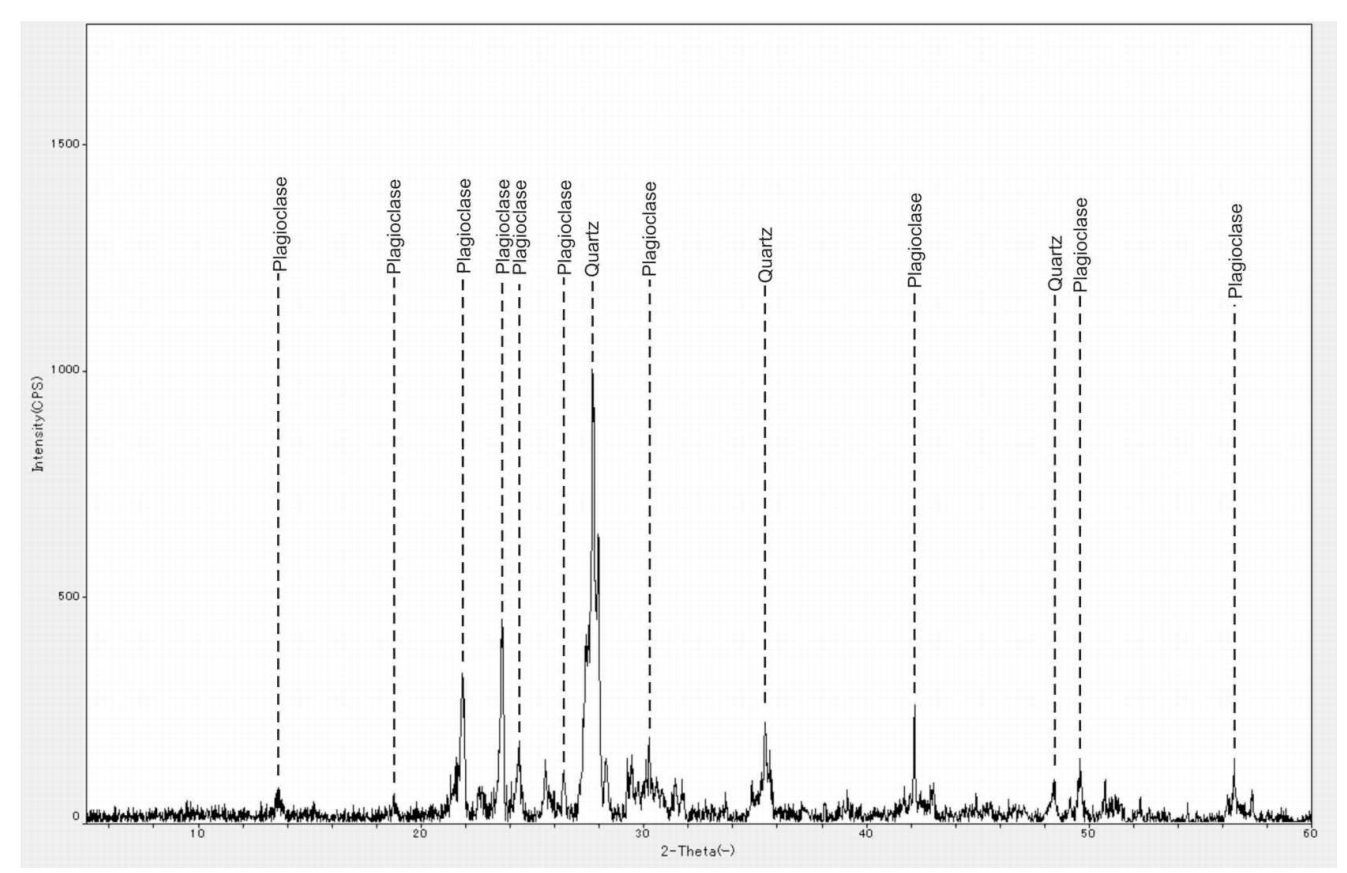

Figure 1: XRD Analysis

determine the potential long-term effects of ash are notably lacking.

Table 2: Result from X-Ray diffraction analysis

\begin{tabular}{l|l}
\hline \multicolumn{1}{c|}{ Ash sample } & Mineralogical composition \\
\hline $\begin{array}{l}\text { Yogyakarta } \\
\text { city }\end{array}$ & Plagioclase, feldspar, quartz \\
\hline Sleman & Plagioclase, feldspar, quartz \\
\hline Sleman & Plagioclase, feldspar, quartz \\
\hline Klaten & Plagioclase, feldspar, quartz \\
\hline Magelang & Plagioclase, feldspar, quartz \\
\hline
\end{tabular}

The U.S. National Institute for Occupational Safety and Health (NIOSH) recommended in 1974 that the exposure to respirable free silica should be limited to 50 micrograms $/ \mathrm{m} 3$ of air for workers up to a 10-hour work day, 40-hour work week over a lifetime. Historical data suggests that this exposure has been exceeded for brief periods of time (hours to days) in certain locations, but not over the working lifetime of people (2-3 decades).

Trace elements content of volcanic ash was presented in Table 3. Total sulfur content was considered high and the source of this sulfur was sulfur dioxide during eruption. The release of sulfur has affected water supplies in study area (Budianta, 2011).
Table 3: Result from trace element analysis

\begin{tabular}{c|c|c|c}
\hline $\begin{array}{c}\text { Trace elements } \\
(\mathrm{ppm})\end{array}$ & $\begin{array}{c}\text { Sample } \\
1\end{array}$ & $\begin{array}{c}\text { Sample } \\
2\end{array}$ & $\begin{array}{c}\text { Sample } \\
3\end{array}$ \\
\hline $\mathrm{Cd}$ & 1.4 & 1.1 & 1.4 \\
\hline $\mathrm{Cu}$ & 33.6 & 23.2 & 30.6 \\
\hline $\mathrm{Pb}$ & 49.5 & 39.5 & 44.5 \\
\hline $\mathrm{Mn}$ & 983.2 & 765.3 & 889.2 \\
\hline $\mathrm{S}$ & 17.2 & 19.1 & 21.4 \\
\hline
\end{tabular}

\section{Conclusion}

This study provides a basis for evaluating some of the key factor which influences the exposure of human to volcanic ash. The factors considered here are the size and composition of volcanic ash. The result demonstrates that Merapi Ash contains high concentration of respirable particles and some heavy metal, therefore it strengthen the view that the ash represents a potential respiratory hazard.

\section{Acknowledgement}

The author is grateful to Head of CHPSC (Center of Health Policy and Social Study), Dr. Susilowati, M.D, which allowed join to the work to be carried out under research collabo- 
ration and to Tifa Foundation for providing research grant.

\section{References}

Baxter, P. J., Bonadonna, C., Dupree, R., Hards, V. L., Kohn, S. C., Murphy, M. D., Nichols, A., Nicholson, R. A., Norton, G., Searl, A., Sparks, R. S. J., and Vickers, B. P., 1999, Cristobalite in Volcanic Ash of the Soufriere Hills Volcano, Montserrat, British West Indies, Science, Vol. 283, pp. 1142-1145.

Budianta, W., 2011, Impact of 2010 Merapi Volcanic eruption in Indonesia for water supplies, In: C. Belvisio, S. Fiore and M.M Giannossi (Editors), Geological and Medical Sciences for a safer Environment, GeoMed2011, Bari, Italy, Digilabs Pub., Bari, Italy, pp. 279

Bonadonna, C., Phillips, J., C, and Houghton, B. F., 2005a, Modeling Tephra Sedimentation from a Ruapehu Weak Plume Eruption, Journal of Geophyscal Research, Vol. 210, B08209, doi:10.1029/2004JB003515.

Bonadonna, C., and Houghton, B, F., Total grain-size distribution and volume of tephra-fall deposits, Bulletin of Volcanology, 2005b, Vol 67, 441-456.

Fiantis, D., Nelson, M., Van Ranst, E., Shamshuddin, J., and Qafoku, N. P., 2009, Chemical weathering of new pyroclastic deposits from Mt. Mer- api (Java), Indonesia, Journal of Mountain Science, Vol. 6, Num. 3, pp. 240-254

Horwell, C. J., and Baxter, P. J., The respiratory health hazards of volcanic ash: a review for volcanic risk mitigation, Bulletin of Volcanology, Vol. 69, pp. 1-24.

Horwell, C. J., Sparks, R. S. J., Brewer, T. S., Llewellin, E. W., and Williamson, B. J., 2003, Characterization of respirable volcanic ash from the Soufrière Hills volcano, Montserrat, with implications for human health hazards, Bulletin of Volcanology, Vol. 65, pp. 346-362.

Horwell, C.J., 2007, Grain-size analysis of volcanic ash for the rapid assessment of respiratory health hazard, Journal of Environmental Monitoring, Vol. 9, pp. 1107-1115

Quality of Urban Air Review Group, 1996, Airborne particulate matter in the United Kingdom, Department of the Environment, London, UK.

Smith, D.B., Zielinski, R.A. and Rose, W.I., 1982. Leachablity of uranium and other elements from freshly erupted volcanic ash, Journal of Volcanology and Geothermal Research, Vol. 13, pp. 1-30.

Voight, B., Constantine, E.K., Siswowidjoyo, S., Torley, R., 2000. Historical Eruptions of Merapi Vocano, Central Java, Indonesia,1768-1998, Journal of Volcanology and Geothermal Research Vol. 100, pp. 69-138. 